\title{
Uji In Vitro Air Rebusan Daun dan Batang Porang (Amorphophallus sp.) Terhadap Pyricularia oryzae Penyebab Penyakit Blas pada Tanaman Padi
}

\author{
Tarkus Suganda ${ }^{*}$, dan Sofia Kholifatu Wahda ${ }^{2}$ \\ ${ }^{1}$ Departemen Hama dan Penyakit Tumbuhan, Fakultas Pertanian, Universitas Padjadjaran \\ ${ }^{2}$ Program Studi Agroteknologi, Fakultas Pertanian, Universitas Padjadjaran \\ Kampus Jatinangor KM 21 Jatinangor 45363 \\ *Alamat korespondensi: tarkus.suganda@unpad.ac.id
}

\begin{tabular}{lrc}
\hline \multicolumn{2}{l}{ INFO ARTIKEL } & ABSTRACT/ABSTRAK \\
\hline Diterima: & 17-06-2021 & \\
Direvisi: & $27-07-2021$ & In vitro Assay of the effect of Aqueous Decoction of Leaves and Stems \\
Dipublikasi:11-08-2021 & of Elephant Foot Yam (Amorphophallus sp.) on Pyricularia oryzae, the \\
& & Pathogen of Rice Blast Disease
\end{tabular}

Keywords:

Colony growth,

Conidial germination

Blast (Pyricularia oryzae) is the most limiting disease of rice in all rice growing regions in the world. Botanical pesticides are explored as an alternative control to reduce the negative impact of synthetic fungicide which has been applied intensively. Various plants have been known to be studied as botanical pesticides against rice blast, but the Elephant Foot Yam (Amorphophallus sp.) which is known to contain antifungal and antibacterial substances and widely used as a medicine for human diseases has never been studied. The aim of this study was to study the effect of aqueous decoction of Elephant Foot Yam's leaves and stems against colony growth and conidial germination of $P$. oryzae. The experiment was carried out in the Laboratory of Phytopathology, Laboratory of Plant Protection Biotechnology, and Laboratory of Pesticide and Toxicology, Department of Plant Pests and Diseases, Faculty of Agriculture, Universitas Padjadjaran in Jatinangor from January 2021 until March 2021. This experiment used Randomized Complete Design (RCD) with seven treatments and four replications. The treatments consisted of control $(0 \%)$, leave and stem aqueous decoction with concentrations of $3 \% ; 4 \% ; 5 \%$. The results of this study showed that elephant foot yam's leaves and stems aqueous decoction inhibited the colony growth of $P$. oryzae with the highest inhibition of $30.6 \%$ showed by concentration of stem decoction of $5 \%$. The highest inhibition effects on conidial germination of $60.6 \%$ was also showed by the concentration of stem decoction of $5 \%$.

Kata Kunci: pertumbuhan koloni, perkecambahan konidia
Penyakit blas (Pyricularia oryzae) merupakan faktor pembatas utama produksi padi di seluruh areal pertanaman padi di dunia. Pestisida nabati dieksplorasi sebagai salah satu alternatif pengendalian untuk mengurangi dampak negatif fungisida yang selama ini digunakan secara intensif. Berbagai jenis tanaman telah diketahui dapat digunakan sebagai pestisida nabati terhadap penyakit blas namun tanaman porang (Amorphophallus sp.) yang diketahui memiliki kandungan senyawa antijamur dan antibakteri serta telah banyak digunakan sebagai obat untuk penyakit manusia belum pernah diujicoba terhadap $P$. oryzae. Tujuan dari penelitian ini adalah untuk menguji pengaruh air rebusan daun dan batang porang dalam menghambat pertumbuhan koloni dan perkecambahan jamur $P$. oryzae secara in vitro. Percobaan dilakukan di Laboratorium Fitopatologi, Laboratorium 
Bioteknologi Proteksi Tanaman dan Laboratorium Pestisida dan Toksikologi Lingkungan, Departemen Hama dan Penyakit Tumbuhan Fakultas Pertanian, Universitas Padjadjaran di Jatinangor pada bulan Januari 2021 sampai Maret 2021. Penelitian menggunakan Rancangan Acak Lengkap (RAL) dengan tujuh perlakuan dan empat ulangan. Perlakuan terdiri atas kontrol (0\%), ekstrak air rebusan daun dan batang porang dengan konsentrasi masing-masing 3\%; 4\%; 5\%. Hasil penelitian menunjukkan bahwa air rebusan daun dan batang porang memiliki kemampuan menghambat pertumbuhan koloni $P$. oryzae dengan penghambatan tertinggi sebesar 30,6\% oleh air rebusan batang konsentrasi 5\%. Penghambatan tertinggi terhadap perkecambahan konidia, yaitu sebesar $60,6 \%$ diperlihatkan juga oleh perlakuan air rebusan batang porang $5 \%$.

\section{PENDAHULUAN}

Tanaman porang (Amorpophallus sp.). merupakan tanaman yang sedang menjadi primadona ekspor. Ubinya, selain untuk bahan pangan, banyak dimanfaatkan dalam bidang medis dan farmasi. Masyarakat Cina menggunakan tepung ubinya sebagai obat tradisional untuk menekan tumor, meredakan dahak, asma, batuk, meredakan luka bakar, gangguan hematologis dan kulit serta digunakan sebagai antioksidan (Chua et al., 2010). Zat kimia yang teridentifikasi terdapat dalam batang dan daun tanaman porang adalah asam hexadecanoic, polysacarida, salviasperanil, 3.5 diacetyltambulin, dan asam tetradeconic (Mallik et al., 2018). Sebagai bahan baku obat, riset tentang pemanfaatan ekstrak tanaman porang baru terbatas pada pemanfaatan ubinya untuk pengobatan penyakit pada manusia, padahal menurut Mallik et al. (2018) tanaman porang memiliki berbagai kandungan senyawa kimia yang berperan sebagai antijamur, antibakteri, zat sitotoksik, imunomodulator, antelmintik (anti cacing), dan hepatoprotektif. Sejauh ini belum ada literatur yang melaporkan hasil riset tentang pemanfaatan ekstrak tanaman porang untuk pengendalian penyakit tanaman. Di Indonesia sendiri, tanaman porang baru dimanfaatkan ubinya sebagai bahan pangan berupa tepung, bahan baku kosmetik, bahan baku industri dan obat-obatan (Sari \& Suhartati, 2015) sedangkan bagian daun dan batangnya belum dilaporkan pemanfaatannya.

Sementara itu, penyakit blas yang disebabkan oleh jamur Pyricularia oryzae merupakan penyakit yang paling merugikan pada tanaman padi, baik di Indonesia (Suganda dkk, 2016; Sudir dkk., 2014) maupun di seluruh dunia (Asibi et al., 2019). Jamur ini menyebabkan kerugian sebesar $\$ 70$ juta per tahun (Scheuermann et al., 2012) dan berpotensi menjadi ancaman bagi ketahanan pangan global (Asibi et al., 2019) karena sekitar 60\% penduduk dunia mengonsumsi beras sebagai makanan pokoknya (Shariar et al., 2020). Penyakit blas sulit dikendalikan walaupun dengan fungisida sintetik, karena jamur ini selain terdiri atas berbagai ras, juga memiliki kemampuan untuk membentuk ras-ras baru (Miah et al., 2017). Oleh karena fungisida sintetik juga tidak ramah lingkungan, maka pencarian metode alternatif untuk pengendaliannya perlu terus dilakukan. Tulisan ini merupakan laporan hasil riset in vitro pengujian ekstrak batang dan daun tanaman porang sebagai antijamur terhadap pertumbuhan koloni dan perkecambahan konidia jamur $P$. oryzae. Ekstrak yang digunakan diperoleh melalui cara perebusan batang dan daun sebagai teknik paling sederhana dalam mengekstrak metabolit sekunder (Wijaya dkk., 2018, Lestari, 2016; Izcan \& Boyraz, 2000).

\section{BAHAN DAN METODE}

Percobaan dilaksanakan di Laboratorium Fitopatologi, Laboratorium Bioteknologi Proteksi Tanaman dan Laboratorium Pestisida dan Toksikologi Lingkungan, Departemen Hama dan Penyakit Tumbuhan Fakultas Pertanian Universitas Padjadjaran di Jatinangor dari bulan November 2020 sampai dengan Januari 2021. Uji aktivitas ekstrak air rebusan simplisia daun dan batang porang terhadap pertumbuhan dan perkecambahan konidia $P$. oryzae dilakukan menggunakan metode ekperimen. Konsentrasi ekstrak air rebusan daun dan batang porang yang diujikan didasarkan kepada uji pendahuluan dengan menentukan terlebih dahulu konsentrasi LC50. Dari hasil uji LC50 ditetapkan terdapat tiga konsentrasi ekstrak daun dan tiga 
konsentrasi ekstrak batang porang, yaitu masingmasing 3\%, 4\% dan 5\% dan satu perlakuan kontrol tanpa ekstrak. Masing-masing perlakuan diulang sebanyak empat ulangan. Data yang diperoleh dianalisis dengan analisis sidik ragam (Anova) menggunakan R program (x64 3.6.1) dan dilanjutkan dengan Uji HSD Tukey pada taraf nyata 5\%.

\section{Pembuatan Ekstrak Batang dan Daun Porang}

Batang dan daun tanaman porang diperoleh dari Bapak Alam, petani porang di Kota Jambi. Batang dan daun porang dicuci bersih dari kotoran dengan air mengalir, kemudian dipotong kecil-kecil untuk mempercepat proses pengeringan. Pengeringan dilakukan menggunakan oven dengan suhu $50^{\circ} \mathrm{C}$ selama 6 jam dan dilakukan berulang sampai mencapai bobot kering bahan yang konstan. Bahan kering kemudian disebut sebagai simplisia, disimpan dalam wadah plastik dalam suhu kamar dengan sirkulasi udara yang baik. Ekstrak dibuat menggunakan simplisia dengan menggunakan metode dekoktasi. Dekoktasi merupakan metode ekstrasi berbasis air panas (Departemen Kesesehatan, 2000). Dekoktasi dilakukan dengan memasukkan 10 $\mathrm{g}$ dari masing-masing simplisia ke dalam panci infusa kemudian ditambahkan $100 \mathrm{ml}$ akuades. Pada panci infusa bawah dimasukan air secukupnya sehingga dapat menutupi infusa dalam Erlenmeyer. Dekoktasi ini dilakukan dengan pemanasan pada suhu $90^{\circ} \mathrm{C}$ selama 30 menit. Hasil dekoktasi kemudian didiamkan selama 24 jam lalu disaring menggunakan kertas saring Whatman no 1 untuk memisahkan residu simplisia dengan larutan esktrak (Al-Manhel \& Niamah, 2012). Untuk menjaga kualitasnya, ekstrak yang dihasilkan disimpan di dalam lemari pendingin pada suhu $4^{\circ} \mathrm{C}$ sampai waktunya digunakan, yaitu maksimum 4 hari setelah proses ekstraksi.

\section{Isolat dan Produksi Konidia Jamur P. oryzae}

Isolat P.oryzae yang digunakan adalah isolat Ras 173 yang diperoleh dari Balai Penelitian Padi di Muara Bogor. Ras ini merupakan salah satu ras yang virulen. Untuk mendapatkan konidia $P$. oryzae, miselium jamur dari biakan agar miring ditumbuhkan kembali pada media Oat Meal Agar (OMA) (30 g oat meal, $20 \mathrm{~g}$ agar, $5 \mathrm{~g}$ sukrose, per liter akuades) selama 7-8 hari pada suhu ruang. Permukaan biakan jamur yang telah memenuhi seluruh permukaan cawan Petri kemudian dicuci dan digosok dengan kuas secara aseptik menggunakan air destilat steril ditambah antibiotik kloramfenikol sebanyak $100 \mathrm{mg} / \mathrm{l}$. Perlakuan ini dimaksudkan untuk menghilangkan hifa aerialnya. Selanjutnya untuk menginduksi pembentukan konidia, biakan jamur yang telah digosok permukaannya tersebut diberi perlakukan penyinaran sinar UV selama 24-48 jam (Manandhar, 1998). Identifikasi jamur dilakukan dengan melihat bentuk konidianya berdasarkan Barnett \& Hunter (1998).

\section{Uji Penghambatan Ekstrak Air Rebusan Simplisia Daun dan Batang Porang terhadap Pertumbuhan Koloni P. oryzae}

Uji kemampuan penghambatan oleh ekstrak air rebusan simplisia daun dan batang porang terhadap pertumbuhan koloni $P$. oryzae dilakukan dengan menggunakan metode poisoned food (Dhingra \& Sinclair, 1994). Pengujian dilakukan dengan menuangkan $10 \mathrm{ml}$ agar+ekstrak dari masing-masing konsentrasi ke dalam cawan Petri. Jamur $P$. oryzae yang diujikan dibuat dengan membuat piringan (disc) berdiameter $5 \mathrm{~mm}$ menggunakan cork borer dari pinggiran koloni $P$. oryzae yang sedang berkembang. Satu piringan kemudian diambil menggunakan jarum ose dan diletakan pada bagian tengah PDA yang telah dicampur dengan ekstrak masing-masing konsentrasi dan kemudian diinkubasikan pada suhu ruang (Sumardiyono dkk., 2011). Pengamatan dilakukan setiap hari dengan mengukur pertumbuhan diameter koloni $P$. oryzae. Pengamatan dihentikan apabila diameter pertumbuhan diameter koloni pada perlakuan kontrol telah memenuhi seluruh permukaan cawan Petri. Perhitungan persentase penghambatan koloni jamur dihitung menggunakan rumus sebagai berikut (Lira-de Leon et al., 2014):

$$
\% \text { penghambatan }=\frac{D k-D p}{D k} \times 100 \%
$$

Keterangan :

$\mathrm{Dk}=$ rata-rata diameter kontrol $(\mathrm{cm})$

$\mathrm{Dp}=$ rata-rata diameter perlakuan $(\mathrm{cm})$

\section{Uji Penghambatan terhadap Perkecambahan Konidia P. oryzae}

Untuk mengetahui kemampuan ekstrak daun dan batang porang dalam menghambat perkecambahan konidia dilakukan dengan metode germination test. Metode yang digunakan merujuk pada pengujian yang dilakukan oleh Widhayasa dkk. (2014). Sebanyak $5 \mathrm{ml}$ ekstrak air daun dan batang 
porang pada masing-masing konsentrasi dimasukan ke dalam tabung reaksi, dan sebagai perlakuan kontrol digunakan akuades steril. Kemudian lima potongan biakan murni $P$. oryzae berumur 14 hari (diameter $5 \mathrm{~mm}$ ) dimasukan ke dalam rabung reaksi setiap ekstrak dan divortex selama tiga menit untuk melepaskan konidianya. Hasil suspensi pada tabung reaksi diambil sebanyak $1 \mathrm{ml}$ menggunakan mikropipet dan diteteskan pada gelas arloji, kemudian diinkubasi di dalam kotak steril yang diberi kertas tissue lembab. Pengamatan dilakukan setelah 24 jam masa inkubasi dan diamati perkecambahannya menggunakan mikroskop pada perbesaran 400x. Suatu konidia dianggap berkecambah jika tabung kecambahnya melebihi setengah panjang konidianya (Steinkellner et al., 2005; dan Wei et al, 2004). Penghitungan jumlah konidia yang berkecambah diamati menggunakan mikroskop dengan menghitung jumlah konidia yang berkecambah. Penghitungan jumlah konidia berkecambah dinyatakan dalam persentase daya kecambah dengan rumus sebagai berikut:

Keterangan :

$$
\mathrm{V}=\frac{\mathrm{T}}{\mathrm{T}+\mathrm{t}} \times 100 \%
$$

$\mathrm{V}=$ Perkecambahan konidia (viabilitas)

$\mathrm{T}=$ Jumlah konidia yang berkecambah

$\mathrm{t}=$ Jumlah konidia yang tidak berkecambah

\section{HASIL DAN PEMBAHASAN}

Efek fungisidal suatu senyawa terhadap jamur patogen biasanya diuji secara in-vitro melalui kemampuannya menghambat pertumbuhan koloni pada medium biakan, terhadap produksi konidia atau spora, dan terhadap perkecambahan konidia. Namun dalam penelitian ini, pengujian hanya dilakukan terhadap pertumbuhan koloni dan perkecambahan konidia karena produksi konidia pada semua perlakuan, kecuali pada perlakuan kontrol, jumlahnya sangat sedikit. Hasil pengujian penghambatan ekstrak air daun dan batang tanaman porang terhadap pertumbuhan koloni biakan $P$. oryzae adalah sebagai berikut.

\section{Penghambatan terhadap Pertumbuhan Koloni $P$. oryzae}

Hasil pengujian secara in-vitro menunjukkan bahwa air rebusan simplisia daun dan batang tanaman porang dapat menekan perkembangan dan pertumbuhan koloni jamur $P$. oryzae (Tabel 1 dan Gambar 1). Secara umum terlihat bahwa ekstrak air batang tanaman porang lebih menekan pertumbuhan koloni $P$. oryzae dibandingkan dengan ekstrak daun tanaman porang.

Rata-rata diameter koloni yang menunjukkan secara statistik berbeda nyata dengan perlakuan kontrol diperlihatkan oleh konsentrasi esktrak batang 3\% dan 5\% dengan masing-masing diameter koloni sebesar $5,2 \mathrm{~cm}$. Penghambatan tertinggi terhadap pertumbuhan koloni pada kedua perlakuan dengan konsentrasi ini masing-masing 30,6\%. Secara statistik, angka penghambatan diameter koloni ini berbeda nyata dengan perlakuan kontrol. Sementara itu, persentase penghambatan pada perlakuan lainnya hasilnya bervariasi. Perlakuan yang memberikan persentase penghambatan rendah yaitu perlakuan ekstrak daun 3\% dan ekstrak daun 5\% dengan persentase pengambatan sebesar 5,3\% dan $2,7 \%$.

Tabel 1. Pertumbuhan koloni P. oryzae pada media PDA yang ditambahi dengan beberapa konsentrasi air rebusan simplisia daun dan batang tanaman porang.

\begin{tabular}{lrlc}
\hline \multicolumn{1}{c}{ Perlakuan ekstrak air } & Rata-rata diameter koloni $(\mathrm{cm})$ & Penghambatan diameter koloni (\%) \\
\hline Kontrol (0\%) & $7,5 \pm 0,50 \quad$ a & - \\
Daun Porang 3\% & $7,1 \pm 0,71 \quad$ abc & 5,3 \\
Daun Porang 4\% & $6,3 \pm 1,07 \quad$ abc & 16,0 \\
Daun Porang 5\% & $7,3 \pm 1,49 \quad$ ab & 2,7 \\
Batang Porang 3\% & $5,2 \pm 0,71 \quad$ c & 30,7 \\
Batang Porang 4\% & $6,7 \pm 0,80 \quad$ abc & 10,7 \\
Batang Porang 5\% & $5,3 \pm 0,53 \quad$ bc & 29,3 \\
\hline \multicolumn{4}{l}{ Keterangan: Angka yang diikuti oleh huruf yang sama menunjukkan tidak berbeda nyata secara statistik berdasarkan Uji HSD } \\
\end{tabular}

Terjadinya penekanan terhadap pertumbuhan biakan $P$. oryzae ini diduga disebabkan oleh kandungan metabolit sekunder, karena sebagaimana telah dilaporkan oleh Mallik et al. (2018) dalam batang dan daun tanaman porang terkandung senyawa metabolit sekunder asam hexadecanoic, 
polysacarida, salviasperanil, 3.5 diacetyltambulin, dan asam tetradeconic. Muthukumaran et al. (2016) juga menambahkan bahwa ekstrak tanaman porang mengandung senyawa alkaloid, fenol, flavonoid, tanin, terpenoid, dan steroid. Senyawa-senyawa ini memiliki peran sebagai antimikroba, salah satunya sebagai antijamur (Mallik et al., 2018; Subhisha \& Subramoniam, 2005; Barile et al., 2006; dan Ghani et al., 2008). Melalui proses ekstraksi yang dilakukan, senyawa-senyawa tersebut diduga dapat larut dalam air sehingga mampu bersifat toksik bagi pertumbuhan jamur $P$. oryzae.

Senyawa-senyawa anti jamur tersebut memiliki peran tersendiri dalam memengaruhi pertumbuhan jamur. Senyawa flavonoid berperan dalam rusaknya sel jamur dan meningkatkan permeabilitas membran sel jamur sehingga sel jamur menjadi terdenaturasi sedangkan senyawa tanin bekerja dengan menghambat penyusunan membran sel jamur melalui penghambatan biosintesis ergosterol (Arifin dkk, 2018). Senyawa alkaloid dapat menyebabkan kematian jamur dengan mekanisme penghambatan sistem respirasi sel dan poliferasi pembentukan protein, menyebabkan kebocoran sel dan hilangnya elektrolit di dalam sel (Swadiyasa dkk, 2019). Mekanisme antijamur oleh senyawa terpenoid disebabkan adanya sifat terpenoid yang hidrofobik sehingga menyebabkan terpenoid dapat melewati dinding sel jamur, mengubah struktur membran sel dan mengganggu proses pembentukan lipid, sedangkan senyawa fenol berpengaruh dalam mendenaturasi ikatan protein pada membran sel sehingga membran sel menjadi lisis (Balafif dkk., 2017). Sementara itu menurut Subhisha \& Subramoniam (2005) adanya kandungan senyawa steroid dalam ekstrak tanaman memiliki peran dalam penghambatan perbanyakan miselia dan perkecambahan spora jamur. Penghambatan oleh ekstrak daun dan batang tanaman porang diduga karena dalam ekstrak tanaman porang terkandung senyawa kimia seperti alkaloid, saponin, tanin, fenol, glikosida, flavonoid dan terpen, yang telah dibuktikan secara fitokimia semua bahan aktif tersebut memiliki efek terhadap jamur $P$. oryzae (Nabila et al., 2019).

Pada penelitian ini, efek penghambatan ekstrak air tanaman porang terhadap pertumbuhan koloni $P$. oryzae, nampaknya tidak terlalu tinggi. Mengacu ke kriteria Mori et al. (1997), besaran persentase penekanan ini termasuk kategori sedang, yaitu berada di kisaran 25\% - 50\%. Tidak terlalu tingginya persentase penekanan ekstrak tanaman terhadap pertumbuhan koloni jamur, juga dilaporkan oleh beberapa peneliti. Begum et al. (2010) yang mencoba 17 jenis ekstrak tumbuhan, hasilnya juga sangat bervariasi dan pengaruhnya sangat tergantung kepada konsentrasi yang digunakan (dose-dependent effects).

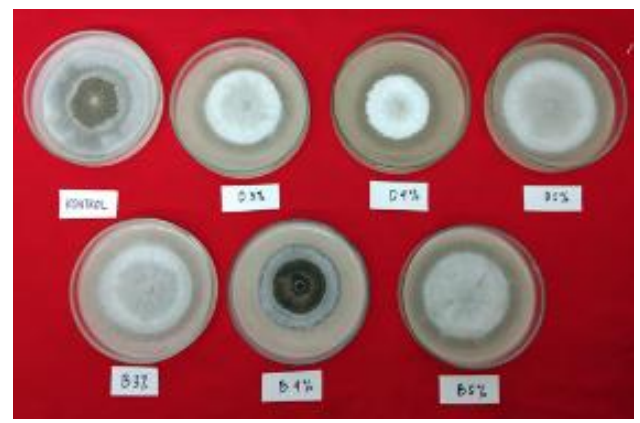

Gambar 1. Penampakan biakan koloni $P$. oryzae yang diberi ekstrak air daun dan batang porang pada berbagai konsentrasi yang diuji $(\mathrm{D}=$ daun, $\mathrm{B}=$ batang).

\section{Penghambatan terhadap Perkecambahan Konidia $P$. oryzae}

Hasil pengujian menunjukkan bahwa ekstrak air batang dan daun tanaman porang juga memperlihatkan efek penghambatan terhadap perkecambahan konidia jamur $P$. oryzae (Tabel 2 dan Gambar 2). Namun demikian, jika mengacu ke data rata-rata jumlah konidia yang berkecambah, secara statistik tidak ada perbedaan antar perlakuan (Tabel 2). Sebagaimana juga dengan efek penghambatan terhadap pertumbuhan koloni, penghambatan yang lebih besar juga ditunjukan oleh ekstrak air batang dibandingkan dengan penghambatan perkecambahan konidia oleh ekstrak air daunnya.

Pengaruh senyawa antijamur dibagi menjadi dua yaitu pengaruh fungistatik dan fungisidal. Menurut Graybill et al. (1997), efek fungistatik ditunjukan dengan adanya penghambatan pertumbuhan jamur sedangkan efek fungisidal ditunjukan dengan kematian jamur patogen. Berdasarkan hal tersebut, dapat diketahui bahwa ekstrak air daun dan batang porang bersifat fungistatik terhadap jamur $P$. oryzae. Berdasarkan hasil penelitian diketahui bahwa walaupun persentase penekanan ekstrak air rebusan simplisia daun dan batang porang rendah terhadap pertumbuhan koloni $P$. oryzae (tertinggi hanya 30,6\%), namun penekanannya terhadap perkecambahan konidia cukup tinggi, yaitu sebesar $60,6 \%$ oleh ekstrak batang konsentrasi 5\%. 
Tabel 1. Rata-rata persentase konidia jamur $P$. oryzae berkecambah dan persentase penghambatan perkecambahannya oleh ekstrak air daun dan batang porang pada berbagai konsentrasi yang diuji.

\begin{tabular}{|c|c|c|}
\hline Perlakuan ekstrak air & $\begin{array}{c}\text { Rata-rata konidia berkecambah } \\
(\%)\end{array}$ & $\begin{array}{c}\text { Penghambatan perkecambahan konidia } \\
(\%)\end{array}$ \\
\hline Kontrol (0\%) & $70,1 \pm 23,0 \mathrm{a}$ & - \\
\hline Daun Porang 3\% & $53,6 \pm 7,9 \mathrm{a}$ & 23,5 \\
\hline Daun Porang $4 \%$ & $60,0 \pm 20,4 \mathrm{a}$ & 14,4 \\
\hline Daun Porang 5\% & $62,1 \pm 18,9$ a & 11,4 \\
\hline Batang Porang 3\% & $37,1 \pm 18,0 \mathrm{a}$ & 47,0 \\
\hline Batang Porang $4 \%$ & $48,9 \pm 10,3 \mathrm{a}$ & 30,2 \\
\hline Batang Porang $5 \%$ & $27,6 \pm 32,1 \mathrm{a}$ & 60,6 \\
\hline $\begin{array}{ll}\text { Keterangan: } & \text { Angka yang diiku } \\
& \text { pada taraf nyata } 5\end{array}$ & huruf yang sama menunjukkan tidak ber & a nyata secara statistik berdasarkan Uji HSD Tukey \\
\hline
\end{tabular}

Gambar 2. Perkecambahan konidia P. oryzae pada perlakuan

(a) kontrol, (b) pada konsentrasi ekstrak daun 3\%, (c) pada ekstrak batang 5\%

Penelitian ini merupakan pengujian pertama untuk mengetahui efek antijamur dari ekstrak air daun dan batang tanaman porang, khususnya terhadap jamur $P$. oryzae karena sejauh ini belum pernah ada laporan serupa dapat ditemukan. Pelarut yang digunakan adalah air, dengan tujuan untuk mengetahui metode pengekstrakan yang paling sederhana, sehingga jika diperoleh hasil yang diharapkan, maka proses ekstraksi nantinya dapat dilakukan sendiri oleh petani. Penggunaan air sebagai pengesktrak tetap layak diujicoba mengingat pada beberapa ekstrak tertentu, ekstrak air tumbuhan terbukti efektif dalam mengekstraksi bahan aktif dari tumbuhan, seperti pada ekstrak air Azadirachta indica terhadap pertumbuhan koloni jamur Phoma oryzae isolat tanaman padi (Iwuagwu et al., 2018). Hubert et al. (2015) juga melaporkan bahwa hanya dengan pelarut air beberapa ekstrak tanaman, seperti tembakau (Nicotiana tabacum), lidah buaya (Aloe vera) dan, bunga krisan (Chrysanthemum coccineum), efektif dalam menghambat lebih dari $80 \%$ pertumbuhan koloni biakan $P$. oryzae.

Penggunaan ekstrak air daun dan batang tanaman porang yang kurang efektif dalam penelitian ini sejalan dengan laporan Cohen (2002) yang menguji ekstrak air Inula viscosa secara invitro terhadap Plasmophara viticola dan Phytophthora infestans. Walaupun kurang menghambat secara in-vitro, pada uji lapangan ekstrak air $I$. viscosa ini ternyata efektif mengendalikan kedua patogen tersebut (Cohen, 2002). Dengan demikian, rendahnya efek penghambatan ekstrak air daun dan batang porang terhadap pertumbuhan koloni dan perkecambahan konidia tetap memberikan peluang untuk dilakukan studi lebih lanjut sebagaimana hasil yang dilaporkan Cohen (2002) tersebut. Selain itu perlu juga dilakukan pengekstraksian bahan aktif tanaman porang dengan menggunakan pelarut selain air.

Cukup tingginya persentase kemampuan air rebusan batang porang dalam menghambat produksi konidia $P$. oryzae memberikan peluang untuk mencegah terjadinya peningkatan inokulum. Sebagaimana diketahui, jamur $P$. oryzae menyebar melalui konidia yang terbawa angin. Rendahnya produksi konidia akan menunda terjadinya epidemi karena produksi konidianya menjadi terhambat. Jamur $P$. oryzae sendiri dipilih berdasarkan nilai kerugian ekonomi yang disebabkannya, serta 
kesulitan dalam pengendaliannya, karena jamur ini dikenal memiliki kemampuan untuk membentuk ras baru dan menjadi resisten terhadap bahan aktif fungisida yang digunakan (Kimura \& Fukuchi, 2018).

\section{SIMPULAN DAN SARAN}

\section{Simpulan}

Berdasarkan hasil pengujian secara in-vitro dapat disimpulkan bahwa:

1. Air rebusan simplisia daun dan batang tanaman porang dapat menghambat pertumbuhan koloni jamur $P$. oryzae dengan penghambatan tertinggi $(30,6 \%)$ ditunjukan oleh air rebusan batang konsentrasi 3\% dan 5\%. Angka persentase aktivitas antijamur air rebusan ini berdasarkan kriteria Morri et al. (1997) termasuk kategori "sedang".

2. Penghambatan tertinggi $(60,6 \%)$ terhadap perkecambahan konidia, ditunjukan oleh air rebusan simplisia batang porang konsentrasi 5\%.

\section{Saran}

Dalam penelitian ini, pengekstrasian bahan aktif dari tanaman porang baru dilakukan dengan pelarut air menggunakan metode dekoktasi. Untuk itu disarankan agar dicoba menggunakan pelarut lainnya serta metode pengekstraksian yang berbeda.

\section{UCAPAN TERIMA KASIH}

Ucapan terima kasih disampaikan kepada Endah Yulia, SP., MSc., PhD. (Kepala Laboratorium Fitopatologi), Fitri Widiantini, SP., MBtS., PhD. (Kepala Laboratorium Bioteknologi Proteksi Tanaman) dan Dr. Ir. Danar Dono (Kepala Laboratorium Pestisida dan Toksikologi Lingkungan) atas fasilitas penelitian yang diberikan, serta Dr. Drs. Martua S. Sianipar, MS. atas diskusinya.

\section{DAFTAR PUSTAKA}

Al-Manhel, AJ, and K Niamah, A. 2012. Effect of aqueous and alcoholic plant extracts on inhibition of some types of microbes and causing spoilage of food. Journal of Nutrition \& Food Sciences, 5 (October). https://doi.org/10.4172/2155-9600.s5-006

Arifin, Z, S Khotimahn, dan S Rahmayanti. 2018. Aktivitas antijamur ekstrak etil asetat daun mangga bacang (Mangifera foetida L.) terhadap Candida albicans secara in vitro. Jurnal Cerebellum 4(3), 1106 - 1119

Asibi, AE, Q Chai and JA Coulter. 2019. Rice blast: a disease with implications for global food security. Agronomy 9:451. 14 pp. doi:10.3390/agronomy9080451.

Balafif, FF, MH Satari, dan D Dhianawaty. 2017. Aktivitas antijamur fraksi air sarang semut Myrmecodia pendens pada Cadida albicans ATCC 10231. MKB, 49(1), 28 -34.

Barile, E, G Bonanomi, V Antignani, B Zolfaghari, SE Sajjadi, F Scala, and V Lanzotti. 2007. Saponins from Allium minutiflorum with antifungal activity. Phytochemistry, 68(5), 596-603.

Barnett, HL and BB Hunter. 1998. Illustrated Genera of Imperfect Fungi 4th. Ed. Burges Pub. Co.

Begum, MF, MF Mahal, and MA Alam. 2010. Inhibition of spore germination and mycelial growth of three fruit rot pathogens using some chemicals fungicides and botanical extracts. Journal of Life Earth Science 5:2327.

Chua, M, TC Baldwin, TJ Hocking, and K Chan. 2010. Traditional uses and potential health benefits of Amorphophallus konjac K. Koch ex NE Br. Journal of ethnopharmacology, 128(2), 268-278.

Cohen, Y, A Baider, B Ben-Daniel and Y Ben-Daniel 2002. Fungicidal preparations from Inula viscosa. Plant Protection Science 38:629-630.

Departemen Kesehatan. 2000. Parameter Kesehatan Umum Tanaman Obat. Jakarta. Departemen Kesehatan.

Dhingra, OD and JB Sinclair. 1994. Basic Plant Plathology Methods 2nd Edition. Florida. CRC Press.

Ghani, SBA, L Weaver, ZH Zidan, HM Ali, CW Keevil, and RC Brown. 2008. Microwaveassisted synthesis and antimicrobial activities of flavonoid derivatives. Bioorganic \& medicinal chemistry letters, 18(2), 518-522.

Graybill, JR, DS Burgess, and TC Hardin. 1997. Key issues concerning fungistatic versus fungicidal drugs. European Journal of Clinical Microbiology \& Infectious Diseases, 16(1), 42-50. doi:10.1007/bf01575120.

Hubert, J, RB Magabala, and DP Mamiro. 2015. Efficacy of selected plant extracts against Pyricularia grisea, causal agent of rice blast 
disease. American Journal of Plant Sciences 6:602-611.

Iwuagwu, CC, FC Onajeme, CC Ononuju, CI Umechuruba, and AC Nwogbaga. 2018. Effects of plant extracts and synthetic fungicides on the radial growth of Phoma oryzae on rice (Oryza sativa L) in some rice growing areas of South Eastern Nigeria. Journal of Plant Pathology and Microbiology 9(12): 5 pp.

Izcan, $\mathrm{M}$, and $\mathrm{N}$ Boyraz. 2000. Antifungal properties of some herb decoctions. European Food Research and Technology, 212(1), 86-88. DOI: $10.1007 / \mathrm{s} 002170000249$

Khan A, M Rahman, and MS Islam. 2008. Antibacterial, antifungal and cytotoxic activities of 3,5- diacetyltambulin isolated from Amorphophallus campanulatus Blume ex. Decne Khan. 32(1), 1-12.

Kimura, N, and A Fukuchi. 2018. MBI-D resistance management of Pyricularia oryzae using an application program incorporating benomyl. Journal of Pesticide Science 43(1): 33-35. doi: 10.1584/jpestics.D17-064.

Lestari, JHS. 2016. Dekok daun kersen (Muntingia calabura) sebagai cairan sanitasi tangan dan buah apel manalagi (Malus sylvestris). Skripsi. Yogyakarta. Universitas Atma Jaya Yogyakarta. Tersedia di http://ejournal.uajy.ac.id/9682/1/JURNALBL01236.p $\mathrm{df}$

Lira-De Leon, KI, MV Ramirez-Mares, V SanchezLopez, M Ramirez-Lepe, R Salas-Coronado, NF Santos-Sanchez, R Valadez-Blanco, and B Hernandez-Carlos. 2014. Effect of crude plant extracts from some Oaxacan flora on two deleterious fungal phytopathogens and extract compatibility with a biofertilizer strain. Frontier in Microbiology 5 Article 383:10 pp.

Mallik, J, J Das, and RK Banik. 2018. Pharmacognostic Profile and Pharmacological Activity of different parts of Amorphophallus campanulatus (Roxb.) Blume-A Complete Overview. Asian Journal of Pharmaceutical Research and Development, 6(1), 4-8.

Manandhar, JB. 1998. Effect of light, temperature, and water potential on growth and sporulation of Microdochium oryzae. Mycologia, $\quad 90(6), \quad 995-1000$. https://doi.org/10.1080/00275514.1998.12026 997
Miah, G, MY Rafii, MR Ismail, M Sahebi, FSG Hashemi, O Yusuf, and MG Usman. 2017. Blast disease intimidation towards rice cultivation: A review of pathogen and strategies to control. The Journal of Animal \& Plant Sciences 27(4):1058-1066.

Mori, M, M Aoyama, S Doi, A Kanetoshi, and T Hayashi. 1997. Antifungal activity of bark extracts of deciduous trees. Holz als Roh Und Wekstoff, 55: 130-132.

Muthukumaran, P, N Saraswathy, S Yuvapriya, R Balan, VB Gokhul, and P Indumathi. 2016. In vitro phytochemical screening and antibacterial activity of Amorphophallus paeoniifolius (Dennst. Nicolson) against some human pathogens. Journal of Chemical and Pharmaceutical Research, 8(2), 388-392.

Nabila, NH, NKCM Ramli, NY Yunus, and SNHM Latip. 2021. Evaluation of selected herbs for biocontrol of rice blast disease. Earth and Environmental Science 685:012026.

Sari, R, and Suhartati. 2015. Tumbuhan porang: prospek budidaya sebagai salah satu sistem agroforestry. Info Teknis EBONI, 12(2), 97110.

Scheuermann, KK, JV Raimondi, R Marschalek, A de Andrade, and E Wickert. 2012. Magnaporthe oryzae genetic diversity and its outcomes on the search for durable resistance. Chapter 15 in The Molecular Basis of Plant Genetic Diversity. InTech. DOI:10.5772/33479.

Shariar, SA; AA Imtiaz, B Hossain, A Husna, M Nurjahan, and K Eaty. 2020. Rice Blast Disease. Annual Research \& Review in Biology. DOI: 10.9734/ARRB/2020/v35i130180.

Steinkellner, S, R Mamerler, and $\mathrm{H}$ Vierheilig. 2005. Microconidia germination of the tomato pathogen Fusarium oxysporum in the presence of root exudates. Journal of Plant Interactions 1(1):23-30.

Subhisha, S, and A Subramoniam. 2005. Antifungal activities of a steroid from Pallavicinia lyellii, a liverwort. Indian Journal of Pharmacology, 37(5), 304

Sudir, A Nasution, dan B Nuryanto. 2014. Penyakit Blas Pyricularia grisea pada Tanaman Padi dan Strategi Pengendaliannya. Iptek Tanaman Pangan, 9(2), 85-96.

Suganda, T, E Yulia, F Widiantini, dan Hersanti. 2016. Intensitas penyakit blas (Pyricularia 
oryzae Cav.) pada padi varietas Ciherang di lokasi endemik dan pengaruhnya terhadap kehilangan hasil Jurnal Agrikultura, 27(3), 154-159.

Sumardiyono, C, T Joko, Y Kristiawati, dan YD Chinta. 2011. Diagnosis dan pengendalian penyakit antraknosa pada pakis dengan fungisida. Jurnal HPT Tropika, 11 (2), 194200.

Swadiyasa, K, NM Puspawati, dan IARA Asih. 2019. Potensi ekstrak daun cendana (Santalum album L.) sebagai senyawa penghambat jamur Candida albicans. Jurnal Kimia (Journal of Chemistry), 13(2), 159 - 165
Wei, L, W Xiu-Fang, and S Cheng-Fa. 2004. Impact of sixteen chemical pesticides on conidial germination of two entomophthoralean fungi: Conidiobolus thromboides and Pandora nouryi. Biocontrol science and technology, 14(7), 737-741.

Widhayasa, B, IK Sastrahidayat, dan S Djauhari. 2014. Perkembahan jamur Alternaria solani dan infeksinya pada sembilan varietas tomat. Jurnal HPT, 4 (3), 102 - 108.

Wijaya, H, Novitasari, dan S Jubaidah. 2018. Perbandingan metode ekstraksi terhadap rendemen ekstrak daun rambai laut (Sonneratia caseilaris L. EngI). Jurnal Ilmiah Manuntung, 4 (1), 79 - 83. 